\title{
ULTRA-PROCESSED FOODS - IS ENOUGH BEING DONE TO REDUCE THEIR CONSUMPTION?
}

Dr. JP Dadhich, MD (Pediatrics)

\author{
Affiliation \\ National Coordinator and Technical Director, Breastfeeding Promotion Network of India (BPNI), \\ Member, International Baby Food Action Network (IBFAN) Global Council \\ Delhi, India
}

\section{Address for Correspondence}

BP-33, Pitampura, Delhi, India, PIN Code: 110034

\section{Email Address}

jpdadhich@bpni.org ; jpdadhich@gmail.com 


\section{ABSTRACT}

The role of ultra-processed foods (UPFs) high in fats, sugar and salt is well documented in the causation of the non-communicable diseases. However, with globalization, consumption of these food products is increasing. In the absence of effective and comprehensive global and national regulatory measures, manufacturers are promoting ultra-processed food products by influencing policymaking, consumer behaviour and research. There is a need to have an international marketing Code, based on which national legal instruments may be enacted to regulate the marketing of UPFs.

KEY WORDS Ultra-processed foods; NOVA classification; Non-communicable diseases; High Fats, Sugar and Salt (HFSS) foods; Obesity

\section{INTRODUCTION}

Ultra-processed foods (UPFs) high in fats, sugar and salt (HFSS) are industrially formulated food products manufactured largely by the Big Food companies. Their contribution to noncommunicable diseases (NCDs) like obesity, insulin resistance and type-2 diabetes, coronary heart disease, high blood pressure and stroke is well documented (WHO,2015; Monteiro et al., 2018; Hu,2011). Ultra-processed foods are formulated and packaged in such a way to make them intensely palatable, have a long shelf life and eliminate the need for culinary preparations. They can be consumed anywhere, anytime. Examples of UPFs are carbonated and other sugar sweetened beverages (SSBs), potato chips, cookies, biscuits, sweets, "nuggets," instant noodles, energy drinks and bars, frozen desserts, ice-cream, infant formula, follow-on formula and fruit drinks (Moodie et al., 2013).

While consumption of ultra-processed food has gained a firm footing in the developed world, globalization is providing Big Food companies access to new markets in middle-income countries. Entry of these companies is leading to a transition in the food habits in these countries by replacing traditional, homemade food with the UPFs, snacks and sugary drinks. Manufacturers of UPFs use predatory techniques to enhance the sale of their products and increase their profits.

This commentary identifies the pattern of UPF consumption and documents promotional methods used by the companies to increase the sales of their products. It also documents global and country level efforts to regulate the marketing and consumption of UPF. Regulation efforts are scattered, inadequate and often riddled with conflicts of interest. This commentary may help in generating a discussion for developing a robust and transparent global and national approach to regulate marketing of UPFs. 


\section{CONSUMPTION OF ULTRA-PROCESSED FOODS IS RISING}

Consumption of UPFs and sugar-sweetened beverages is increasing rapidly, replacing use of natural, traditional, indigenous, culturally acceptable freshly cooked food (Moodie, 2013; WHO, 2010a). An analysis of per capita sales of UPFs including frozen products, snacks (which include sweet and savoury snacks, confectionery, and ice cream) and soft drinks in 79 high and lowincome countries between 1998 and 2012 has revealed a consistent rise in the sales of frozen products in all the countries, while middle-income countries have recorded a consistent increase in the sales of snacks and soft drinks (Monteiro et al., 2013). According to a study of 19 European countries, availability of UPFs at household level ranged between $10.2 \%$ (in Portugal) to $50.4 \%$ (in the U.K.). Importantly, there was a significant positive association between the availability of the UPFs and the prevalence of adult obesity at national level in these countries (Monteiro et al., 2018).

Another study (Rauber et al., 2018) found that UPFs contributed $56.8 \%$ of energy on average in the U.K population. The study also found that high consumption of UPFs correlated with lower intake of protein, fibre, and potassium and a higher intake of carbohydrates, free sugars, total fats, saturated fats, and sodium, thereby increasing the risk of diet-related NCDs. An assessment of the ultra-processed food market and the nutrition transition in Asia found that sales of the UPFs have increased rapidly in most middle-income countries of the region. Carbonated soft drinks lead in this expansion. The study reported that companies based in the United States and Europe lead the market (Baker and Friel, 2016). It has been estimated that in India, per capita sugar consumption from SSBs increased from $0.48 \mathrm{~kg}$ in 2005 to $1.11 \mathrm{~kg}$ in 2011 . Meanwhile, the number of persons suffering from type-2 diabetes in India increased from 40.9 million in 2007 to 65.1 million in 2013 (Gulati and Misra, 2014). A study from Brazil reported gradual displacement of long-established traditional food by UPFs and noted that their contribution to energy intake rose from less than $20 \%$ of calories in the 1980 s to $28 \%$ in 2011 (Monteiro et al., 2011).

\section{METHODS MANUFACTURERS USE TO PROMOTE THEIR BRANDS AND PRODUCTS}

The primary obligation of transnational food corporations, like any other for-profit companies, is to maximize profits for their shareholders. They directly or indirectly try to influence international and national policymaking and regulatory mechanisms, scientific research, and program implementation related to food and nutrition to enhance sales of their products. They also attempt to influence consumer behaviour to increase consumption of UPFs. Some of the methods they use are described below. 


\section{Influencing international and national policy making}

The food industry and its associations participate in various international and national policy making processes. For example, food industry associations participate as observers in the Codex Committee on Nutrition and Food for Special Dietary Uses (CCNFSDU). Food industry representatives are also included in the official delegations of the member states. In the 2017 CCNFSDU meeting in Berlin, of the 350 delegates listed as participants, $40 \%$ were from food industries and their associations. Some participated in the meeting as members of official government delegations (Baby Milk Action, 2018). In the Codex Committee on Food Labeling meeting held in Paraguay in October 2017, Coca-Cola representatives were part of many country delegations including Argentina, Chile, Costa Rica, India, Nigeria, and the United States (Codex Alimentarius Commission, 2017). Participation in the Codex meetings as an official country delegate provides the food industry representatives an opportunity to influence important policy decisions in their favour. In India, many national Codex committees have industry representatives as members, thus giving them an opportunity to influence national policy decisions on agenda items being discussed (FSSAI, 2015).

\section{Resisting statutory regulations and opting for self-regulation}

The food industry resists attempts to enact statutory regulations for marketing of its products. Instead, it strives for having self-regulations or industry-friendly regulations. This is done mainly to avoid statutory and binding regulations and to facilitate their marketing activities to increase sales and generate more profits (Mallarino et al, 2013). Self-regulation does not work, as is evident from an analysis of the effectiveness of the self-regulatory Canadian Children's Food and Beverage Advertising Initiative. It found a great deal of advertising of HFSS food products on children's preferred websites (Potvin and Pauzé, 2018). A study from Australia found that selfregulation did not decrease children's exposure to 'unhealthy food' advertisements on television (Watson et al, 2017). A comparison of compliance with 'the Spanish Code of self-regulation of food and drinks advertising directed at children under the age of 12 years' revealed that noncompliance with the Code has increased over time (León-Flández et al., 2017).

\section{Taking advantage of trade liberalization to expand the ultra-processed food market}

Liberalization of global trade has resulted in free trade agreements between countries that remove or reduce trade and investment barriers, thus facilitating financial investment, and enhancing the markets. The food industry has utilized such agreements to its benefit. One example is the North American Free Trade Agreement (NAFTA) between the USA, Canada and Mexico, signed in 1994, which opened the markets for foreign direct investment (FDI) and gradually eliminated tariffs and duties (Office of the United States trade representative, 2018). Lowering of tariffs on caloric sweeteners like high fructose corn syrup (HFCS) led to a marked rise 
in HFCS supply in Canada and Mexico (Barlow et al., 2017; McMillan, 2015). An analysis of the flow of food products from the United States to Mexico over the NAFTA period has found that Mexico's food environment has become obesogenic due to the trade agreement leading to an increased prevalence of obesity (Clark et al., 2012). In Mexico, average per capita consumption of Coca-Cola increased from 290 eight-ounce servings in 1991 to 745 servings in 2013 (Siegel AD, 2016).

Another analysis, which compared consumption of soft drinks in low-middle income countries that entered into FTAs with the United States to those that did not revealed that these FTAs resulted in a per capita 63.4\% higher level of soft drink consumption (Stuckler et al, 2012). FDI has helped the food industry to expand their market in developing countries, e.g. in Asia, where FDI from the food industry increased from US\$743 million to US\$2.1 billion and in Latin America, where it increased from US\$222 million to US\$3.3 billion between 1988 and 1997 (FAO, 2004).

\section{Influencing consumer behaviour through advertisements}

In the globalized world, transnational food corporations and 'Big Food' companies with huge financial strength are shaping consumers' choices and food habits through innovative promotional methods.

Advertising these products on mainstream media like television is a preferred way for the food industry to promote their products. This gives them an opportunity to directly reach consumers. They promote HFSS products such as instant noodles, fruit drinks, and other unhealth drinks as being safe, healthy and nutritious food products. In addition to television advertisement, children are targeted with product placement in television programmes and films; sponsorships of children's programs on TV; sponsorship of sports events; packaging food products in attractive containers, sometimes as animal shaped products; providing in-pack gifts; displaying products at special points of sales, and installing vending machines in schools.

A study from Argentina reported that children are exposed to an estimated sixty-one advertisements of unhealthy processed and UPF products like desserts, sweetened dairy products, non-alcoholic sugary beverages, fast-food restaurants, and salty snacks per week (Allemandi, 2018).

\section{Posing as responsible nutrition actor and creating a positive image}

To influence public opinion in their favour, the food industry presents itself as a responsible actor in the field of food and nutrition. It piggy-backs on public health campaigns the way baby food companies have used UNICEF's '1000 days campaign' (Breastfeeding Promotion Network of India, 2012); World Breastfeeding Week (Baby Milk Action, 2015) and other socio-cultural festivals and events. In 2008, Cadbury, a leading manufacturer of chocolates and other snack 
foods, partnered with UNICEF Canada to provide funds to construct schools in two African countries, and in return, Cadbury used UNICEF logo on the labels of its products with a promotional massage about the partnership (Lancet Editorial, 2010).

In India, the food industry has collaborated with civil society organizations, media organizations, and public institutions to run campaigns. For example a campaign for the education of girls by Nestle in collaboration with the 'Nanhi kali' voluntary organization (Nestle India Limited, 2018); 'Support My School' program by Coca-Cola in collaboration with a TV channel NDTV (NDTV, 2018) and reaching out to adolescent girl children in schools in collaboration with public universities with the pretext of nutrition education as part of Nestlé Healthy Kids Global Program (Nagarajan, 2011).

\section{Influencing bio-medical research}

Bio-medical research papers published in the peer-reviewed journals are crucial in developing clinical guidelines, formulating national policies, and making patient care decisions. Therefore, bio-medical research should be kept free from fraud, misconduct and conflicts of interest (Dadhich JP. 2012). However, the food industry has influenced research outcomes and the direction of the debate on nutrition and health issues through sponsorship to researchers and their professional associations.

One of the best documented examples of this comes from an analysis of internal industry documents from 1965 (Kearns et al, 2016). It revealed that the Sugar Research Foundation (SRF), the sucrose industry's Washington, DC-based trade association, sponsored research to review dietary causes of coronary heart disease. This review suggested fat and cholesterol as the major dietary causes of coronary heart disease while downplaying the role of sucrose as a risk factor, ignoring available evidence. The facts that SRF funded the research, had a role in the setting of review's objective, contributed articles for inclusion, and received drafts for comments were not disclosed in the published review. As a result, the role of sugar in causing coronary heart disease was not properly analysed.

Another example of efforts to influence scientific research is the financial and logistical support by Coca-Cola to a group of scientists of the Global Energy Balance Network (GEBN) in the USA. Internal company documents revealed that Coca-Cola presented GEBN as an 'honest broker' and wanted it to serve as a 'weapon' to 'change the conversation' about obesity. GEBN promoted the idea that exercise is key to health and weight loss rather than the consumption of sugary drinks (Barlow et al, 2018). 


\section{Sponsoring sports events}

The food industry finds sports to be a very effective platform for promoting its brands, especially among the youth. Sponsorship of sports also provides legitimacy to the food industry as responsible actors in nutrition, health and well being. Many of the media campaigns and sponsorships target children, in spite of the fact that consumption of ultra-processed food products including SSBs has been cited as an important factor in the causation of obesity. The food industry sponsors international and national sports events (Bhutan Football Federation, 2018); sports clubs and associations (FC Barcelona, 2016); runs media campaigns during major sports events (Campaign US, 2016) and hires celebrity sports persons as brand ambassadors (Pepsico India, 2010) to promote their products. Coca-Cola has been a sponsor of the Olympics movement since 1928, making it the longest continuous sponsor (The Olympic games, 2018).

\section{Forging partnerships with health and nutrition organizations}

The food industry partners with and sponsors health and nutrition professional organizations and in return it gets legitimacy to promote its products as healthy and nutritious. This also helps the food industry in its efforts to resist policies such as a soda tax (Freedhoff and Hébert, 2011). Such partnerships also provide them an opportunity to get audience with the subject experts. For example, in the World Congress on Developmental Origins of Health and Disease (DOHaD) organized in Singapore in 2013, the main sponsors were Danone, Nutricia, Nestle, and Novo Nordisk. These corporate entities were allowed to host symposiums on specific issues and their representatives were included as speakers in a plenary session to speak on public-private partnerships and the positive contributions of the food industry (Horton R, 2017).

\section{ACTION SO FAR TO REGULATE MARKETING AND CONSUMPTION OF ULTRA-PROCESSED FOODS}

The World Health Organization and governments have taken initiatives to regulate marketing and consumption of UPFs. Such initiatives include adopting a World Health Assembly resolution, developing guidelines for marketing of foods and non-alcoholic drinks, levying extra tax on UPFs, and restricting direct advertising of HFSS foods to children. Some salient examples are given here.

Recognizing the health risks of processed and UPFs, the World Health Assembly (the supreme decision-making body of the World Health Organization) adopted resolution 63.14 in 2010 which set out agreed recommendations on the marketing of foods and non-alcoholic beverages to children (WHO, 2010b). The document says, "...the effectiveness of marketing is a function of exposure and power, the overall policy objective should be to reduce both the exposure of children to, and power of, marketing of foods high in saturated fats, trans-fatty acids, free sugars, or salt" (WHO, 2010c). Subsequently, in 2012, WHO published "A framework for implementing the set of recommendations on the marketing of foods and non-alcoholic beverages to children" 
which dealt with the marketing of such foods to children, developing and implementing policies to regulate their marketing and establishing an effective monitoring and evaluation system (WHO, 2012).

In light of the slow progress in addressing NCDs, the WHO Secretary General convened the WHO Independent High-Level Commission on Non-communicable Diseases in October 2017 to seek advice for accelerating progress on combating NCDs (WHO Independent High-level Commission on NCDs, 2018). The commission developed a report, 'Time to Deliver,' with recommendations for member states to take action on curbing the NCDs. However, the commission did not involve public interest civil society organization in the development of this report. The report suggests involving private sector as a stakeholder in combating the NCDs, and also recommends voluntary measures by them such as reformulation and self-regulation for promotion of food products (WHO, 2018). Consequently, public health nutrition professionals have submitted comments to the WHO Independent High-Level Commission on Non-communicable Diseases (NCDs) on this report (Public health nutrition professionals, 2018). [Editor's note: this letter is published in this issue of WN.]

The Committee on the Rights of the Child oversees implementation of a major human rights treaty, the Convention on the Rights of the Child (CRC). The committee has recognized marketing of unhealthy food and associated risk of obesity as a child rights issue. Referring to section 24 of the CRC, in 2015, the Committee called upon governments of many countries, including Switzerland, Poland, Brazil, United Arab Emirates, and Chile, to regulate marketing of unhealthy foods, especially when such marketing is targeting children (UNICEF, 2018).

At country level, several countries have enacted laws to regulate the advertising, prescribed guidelines for front of the pack labelling, regulating exposure of children to HFSS foods and levied extra tax on the HFSS foods. The United Kingdom government introduced regulations with scheduling and content restriction on TV advertising of HFSS foods in or around programmes aimed at children. Under these regulations, advertisements of HFSS food or drink products, as specified in the nutrient-profiling scheme of the Food Standards Agency, are prohibited. A review one year after these regulations revealed a significant reduction in exposure of children to advertisements of HFSS products and a decreased annual expenditure for child-themed food and drink advertisements across all media (Office of communication, 2008). Similarly, Brazil has launched the 'Strategic Action Plan to Tackle Non-Communicable Diseases in Brazil' with decreasing childhood obesity as one of its goal. The Inter-ministerial Ordinance by the Ministry of Health and Education has provided guidelines to encourage consumption of healthy foods in the schools (Silva et al, 2013).

Several countries have effectively used extra tax on UPFs to restrict their consumption. This is evident from the experience in Mexico, with tax on SSBs; Hungary, with a tax on HFSS foods and drinks; Finland, with tax on sweets, ice-cream and soft drinks; and France, with tax on SSBs. Experience from these countries show that it is possible to achieve a positive behaviour change and reduction in the consumption of specific food products in addition to raising revenue with 
the imposition of a sugar tax (Editorial - The Lancet Diabetes Endocrinology, 2017; Diniz Silva et al., 2016).

Modelling studies have estimated significant reductions in obesity (Andreyeva et al., 2011; Manyema et al., 2015) and diabetes with the imposition of such a tax and the resultant reduction in the consumption of SSBs. However, for the long-term effect of reduced consumption of HFSS foods on non-communicable diseases and health, further research and evaluation using public funds is required (Diniz Silva et al., 2016).

\section{WHAT MORE NEEDS TO BE DONE?}

With the recognition of role of UPFs in causing NCDs, scattered and selective efforts have been made to regulate their marketing and reducing their consumption. However, more needs to be done to effectively reduce their consumption. A comprehensive documentation of national efforts and evaluation of their impact may be a first step. More importantly, a global marketing code should be adopted, based on which national legal instruments may be enacted. Such a Code should provide recommendations for prohibiting UPFs advertising and promotion, particularly to children; prohibiting sponsorship of research, sports and academic activities by UPF manufacturers, and developing a system for monitoring and implementation of the code. The code should also prohibit participation of UPF manufacturers in national and international policymaking and programme implementation.

\section{REFERENCES}

Allemandi L, Castronuovo L, Tiscornia MV et al. 2018. Food advertising on Argentinean television: are ultra-processed foods in the lead? Public Health Nutrition 21(1):238-246

Andreyeva T, Chaloupka FJ, Brownell KD. 2011. Estimating the potential of taxes on sugarsweetened beverages to reduce consumption and generate revenue. Prev Med 52(6):413-6.

Baby Milk Action. 2015. Nestlé hijacking World Breastfeeding Week again. Available at: http://www.babymilkaction.org/archives/5365 Accessed on June 28, 2018.

Baby Milk Action. 2018. French and US Trade delegations put child health at risk. Available at: http://www.babymilkaction.org/archives/15887 Accessed on June 29, 2018

Baker P, Friel S. 2016. Food systems transformations, ultra-processed food markets and the nutrition transition in Asia. Global Health 12(1):80.

Barlow P, McKee M, Basu S, Stuckler D. 2017. Impact of the North American Free Trade Agreement on high-fructose corn syrup supply in Canada: a natural experiment using synthetic control methods. Canadian Medical Association Journal 189(26):E881-E887. 
Barlow P, Serôdio P, Ruskin G et al. 2018. Science organisations and Coca-Cola's 'war' with the public health community: insights from an internal industry document. Journal of Epidemiology and Community Health. pii: jech-2017-210375. doi: 10.1136/jech-2017210375.

Bhutan Football Federation. 2018. Bhutan $\mathrm{MILO}^{\circledR}$ Cup 2018. Available at:

https://www.bhutanfootball.org/bhutan-milo-cup/ Accessed on August 12, 2018.

Breastfeeding Promotion Network of India. 2012. Nestlé does a

greenwash. Available at: https://www.bpni.org/nestle-does-a-greenwash Accessed on June 28,2018

Campaign US. 2016. How Coca-Cola targeted teens during the 2016 Olympic Games. Available at:https://www.campaignlive.com/article/coca-cola-targeted-teens-during-2016olympic-games/1406187 Accessed on June 29, 2018

Clark SE, Hawkes C, Murphy SM et al. 2012. Exporting obesity: US farm and trade policy and the transformation of the Mexican consumer food environment. International Journal of Occupational and Environmental Health 18(1):53-65.

Codex Alimentarius Commission. 2017. Report of the forty-fourth session of the codex committee on food labeling. Available here Accessed on June 29, 2018

Dadhich JP. 2012. Tackling conflict of interest and misconduct in biomedical research. Indian Pediatrics 49(7):527-31.

Diniz Silva AC, Tan HL, Rawof $\mathrm{N}$ et al. 2016. Implementation of a "food tax" to prevent obesity: A critical appraisal. Diabetes \& Primary Care 18: 126-30.

Editorial - The Lancet Diabetes Endocrinology. 2017. Sweet success: will sugar taxes improve health? Lancet Diabetes Endocrinology 5(4):235.

FAO. 2004. The state of food insecurity in the world 2004: Monitoring progress towards the World Food Summit and Millennium Development Goals, Rome, Food and Agriculture Organisation. Available at: http://www.fao.org/docrep/007/y5650e/y5650e00.htm Accessed on June 22, 2018.

FC Barcelona. 2016. Nestlé Milo becomes a new global sponsor of FC Barcelona for the next four years. Available at: https://www.fcbarcelona.com/club/news/2016-2017/nestle-milobecomes-a-new-global-sponsor-of-fc-barcelona-for-the-next-four-years Accessed on June 29, 2018 
Freedhoff Y, Hébert PC. 2011. Partnerships between health organizations and the food industry risk derailing public health nutrition. Canadian Medical Association Journal 183(3):291-2.

FSSAI. 2015. Order on constitution of national codex committee (NCC) and shadow committees under NCC. Available at: http://old.fssai.gov.in/Codexindia/PDF/Codex Order.pdf Accessed on June 29, 2018

Gulati S, Misra A. 2014. Sugar intake, obesity, and diabetes in India. Nutrients 6(12):595574.

Horton R. 2017. Offline: NCDs-why are we failing? Lancet 390(10092):346.

Hu FB. 2011. Globalization of diabetes: the role of diet, lifestyle, and genes. Diabetes Care 34(6):1249-57.

Kearns CE, Schmidt LA, Glantz SA. 2016. Sugar industry and coronary heart disease research: A historical analysis of internal industry documents. JAMA Internal Medicine 176(11) : 16801685.ola

Lancet Editorial. 2010. Trick or treat or UNICEF Canada. Lancet 6;376(9752):1514.

León-Flández K, Rico-Gómez A, Moya-Geromin MÁ et al. 2017. Evaluation of compliance with the Spanish Code of self-regulation of food and drinks advertising directed at children under the age of 12 years in Spain, 2012. Public Health 150:121-129.

Letter by public health nutrition professionals to the WHO Independent High-Level Commission on Non-communicable Diseases (NCDs). [Published in this issue of WN]

Mallarino C, Gómez LF, González-Zapata L et al. 2013. Advertising of ultra-processed foods and beverages: children as a vulnerable population. Rev Saude Publica. 2013 Oct;47(5):1006-10. Erratum in: Rev Saude Publica;47(5):1010. Rev Saude Publica;48(1):191.

Manyema M, Veerman JL, Chola L et al. 2015. Decreasing the burden of type 2 diabetes in South Africa: The impact of taxing Sugar-Sweetened Beverages. PLoS One 10(11):e0143050.

McMillan T. 2015. How NAFTA changed American (and Mexican) food forever. NPR. Available at: https://www.npr.org/sections/thesalt/2015/02/13/385754265/how-naftachanged-american-and-mexican-food-forever Accessed on June 28, 2018.

Monteiro CA, Levy RB, Claro RM et al. 2011. Increasing consumption of ultra-processed foods and likely impact on human health: evidence from Brazil. Public Health Nutrition 14(1):5-13. 
Monteiro CA, Moubarac JC, Cannon G et al. 2013. Ultra-processed products are becoming dominant in the global food system. Obesity Review 14 Suppl 2:21-8.

Monteiro CA, Moubarac JC, Levy RB et al. 2018. Household availability of ultra-processed foods and obesity in nineteen European countries. Public Health Nutrition 21(1):18-26.

Moodie R, Stuckler D, Monteiro C et al. 2013. Profits and pandemics: prevention of harmful effects of tobacco, alcohol, and ultra-processed food and drink industries. Lancet 381(9867):670-9.

Nagarajan R. Nestle's secret pact with universities irks activists. Available here: Accessed on June 28, 2018

NDTV. 2018. Coca-Cola NDTV Support My School. Available at:

https://www.ndtv.com/supportmyschool Accessed on June 28, 2018

Nestle India Limited. 2018. Nanhi Kali. Available at:

https://www.nestle.in/featuredstories/nanhi-kali Accessed on June 28, 2018.

Office of communication. 2008. Changes in the nature and balance of television food advertising to children A review of HFSS advertising restrictions. Available at: https://www.ofcom.org.uk/ data/assets/pdf file/0028/23977/hfssdec08.pdf Accessed on June 27, 2018

Office of the United States trade representative. 2018. North American Free Trade Agreement (NAFTA). Available at: https://ustr.gov/trade-agreements/free-tradeagreements/north-american-free-trade-agreement-nafta Accessed on June 25, 2018.

Pepsico India. 2010. Salman Khan appointed as the brand ambassador for Mountain Dew. Available at: http://www.pepsicoindia.co.in/media/Press-Releases/release 1230 10.aspx Accessed on August 12, 2018

Potvin KM, Pauzé E. 2018. The effectiveness of self-regulation in limiting the advertising of unhealthy foods and beverages on children's preferred websites in Canada. Public Health Nutr;21(9):1608-1617.

Rauber F, da Costa Louzada ML, Steele EM et al. 2018. Ultra-processed food consumption and chronic non-communicable diseases-related dietary nutrient profile in the UK (2008-2014). Nutrients 9:10(5).

Siegel AD. 2016. NAFTA largely responsible for the obesity epidemic in Mexico, 50 Washington University Journal of Law \& Policy 195. Available at: http://openscholarship.wustl.edu/law journal law policy/vol50/iss1/9 Accessed on June 28, 2018. 
Silva AC, Bortolini GA, Jaime PC. 2013. Brazil's national programs targeting childhood obesity prevention. International Journal of Obesity Suppl 3(Suppl 1):S9-S11.

Stuckler D, McKee M, Ebrahim S et al. 2012. Manufacturing epidemics: the role of global producers in increased consumption of unhealthy commodities including processed foods, alcohol, and tobacco. PLoS Medicine 9(6):e1001235.

The Olympic Games. 2018. Coca-Cola and the Olympic games celebrate 90 years of partnership. Available At: https://www.olympic.org/sponsors/coca-cola Accessed on June 29,2018

UNICEF. 2018. A child rights-based approach to food marketing: a guide for policy makers. Available here Accessed on 27 June 2018.

Watson WL, Lau V, Wellard L et al. 2017. Advertising to children initiatives have not reduced unhealthy food advertising on Australian television. J Public Health (Oxf);39(4):787-792.

WHO Independent High-level Commission on NCDs. 2018. Available at:

http://www.who.int/ncds/governance/high-level-commission/en/ Accessed on July 29, 2018.

WHO. 2010a. Pacific islanders pay heavy price for abandoning their traditional diets. Bulletin of the World Health Organization, 88(7), 484-485.

http://doi.org/10.2471/BLT.10.010710

WHO. 2010b. Resolution 63.14 in the sixty third World Health Assembly, 17-21 May 2010. Geneva. Available at: http://apps.who.int/gb/ebwha/pdf files/WHA63-REC1/WHA63 REC1P2-en.pdf Accessed on June 24, 2018.

WHO. 2010c. Set of recommendations on the marketing of foods and non-alcoholic beverages to children. Available at: http://apps.who.int/iris/bitstream/10665/44416/1/9789241500210 eng.pdf Accessed on June 28, 2018.

WHO. 2012. A framework for implementing the set of recommendations on the marketing of foods and non-alcoholic beverages to children. World Health Organization.http://www.who.int/iris/handle/10665/80148

WHO. 2015. Factsheets: Healthy diets. Available at: http://www.who.int/en/newsroom/fact-sheets/detail/healthy-diet Accessed on June 23, 2018.

WHO. 2018. Time to deliver: report of the WHO Independent High-level Commission on Non-communicable Diseases. Geneva: World Health Organization; 2018. Licence: CC BY-NC SA 3.0 IGO. Available here Accessed on July 29, 2018 